УДК 614.31:637'8.07:597.556.333.1.086:591.436:639.2.09:576.895.132

(C) 2017

Моргун О. А., завідувач відділу ветеринарно-санітарної експертизи

Миколаївська регіональна лабораторія ветеринарної медицини

Сорока Н. М., доктор ветеринарних наук, професор

Національний університет біоресурсів і природокористування України

\title{
ГІСТОЛОГІЧНІ ЗМІНИ У ПЕЧІНЦ БИЧКОВИХ РИБ, ЗАРАЖЕНИХ ЛИЧИНКАМИ НЕМАТОДИ EUSTRONGYLIDES EXISUS
}

\section{Рецензент - доктор ветеринарних наук Ю. Ю. Довгій}

\begin{abstract}
Наведено гістологічні зміни у печінці бичківпісочників, заражених личинками нематоди Eustrongylides exisus. Виявлено патологічний прочес та структурні зміни в органі, щзо характерні для вогнищевого гепатиту. Гепатоцити збільшені в об'ємі, округлої форми, ядро відтиснене до оболонки клітини. Ядра зменшені в об'ємі, неправильної форми (пікноз). Відмічається лізис ядер. В окремих ділянках виявлені клітини Купфера. Помітні лімфоїднлейкочитарні інфільтрати в паренхімі печінки, периваскулярні та ендоваскулярні муфти. У зонах клітинних інфільтратів ядра в гепатоичтах відсутні. Відмічено, ш⿻ гепатоцити представлені аморфною безструктурною масою. В окремих місиях навколо клітинних інфільтратів виявлено розростання сполучної тканини, щуо є захисною реакиією організму на наявність личинок нематоди Eustrongylides exisus.
\end{abstract}

Ключові слова: бичок-пісочник, личинки Eustrongylides excisus, печінка, гепатоцити.

Постановка проблеми. Значний інтерес представляє стан печінки бичків-пісочників (Neogobius fluviatilis) як цінної промислової риби. Подібно до інших залоз, печінка складається iз паренхіми та строми. Паренхіма представлена епітеліальними клітинами ентодермального походження, які називають печінковими клітинами, або частіше, гепатоцитами. Паренхіма печінки риб, на відміну від вищих хребетних, не має часточкової будови. За М. І. Григор'євим, печінка нижчих хребетних, зокрема костистих риб, трубчастої будови, що на гістологічних зрізах має вигляд балок. Останні складаються з багатокутних клітин, що тісно примикають одна до другої [5].

Личинки нематоди Eustrongylides exisus локалізуються у рибі в черевній порожнині тіла, стінках кишечника, печінці, спинній м'язовій тканині, сім'яниках і $є$ патогенними для організму та часто викликають у них масові захворювання $[5,6]$.

Тому для визначення патогенного впливу личинок нематоди Eustrongylides exisus на організм важливими $є$ гістологічні дослідження печінки бичків-пісочників.

Аналіз основних досліджень і публікацій, у яких започатковано розв'язання проблеми. Нині накопичено великий фактичний матеріал 3 вивчення структурно-функціональних змін у печінці риб як у нормі, так і за різних зовнішніх впливів. Відомо, що структурно-функціональні зміни у печінці риб частіше виникають за дії фізичних і хімічних факторів, які характеризуються зернистою дистрофією, вакуолізацією цитоплазми гепатоцитів, некробіозом та іншими порушеннями $[1,2,8]$. Крім того, у печінці риб виявляються морфологічні ознаки гепатиту і цирозу, судинні розлади різного ступеня, включаючи геморагії і плазморагії, деструкції і розпад тканин, дистрофії $[3,7]$. Печінка у птахів та ссавців - частковий орган. Нині будова печінки гомойотермних тварин вивчена досить повно. Водночас роботи присвячені визначенню гістологічних змін у печінці у випадку зараження риби паразитами, малочисельні [4].

Метою досліджень було вивчення гістологічних змін у печінці бичків-пісочників, заражених личинками нематоди Eustrongylides exisus.

Матеріали і методи досліджень. 3 неблагополучної водойми Дніпробугського лиману (мис Аджигол) для досліджень відібрали 10 бичківпісочників (Neogobius fluviatilis), заражених личинками нематоди Eustrongylides exisus. Гістологічні дослідження печінки риб проводили у відділі патоморфології Миколаївської регіональної лабораторії ветеринарної медицини.

Відібрані шматочки печінки риб фіксували у $10 \%$ нейтральному формаліні. Потім зневоднювали у спиртах зростаючої концентрації та через хлороформ заливали у парафін. Виготовляли гістологічні зрізи товщиною 2-3 мкм, фарбували ïх гематоксиліном Ерліха та еозином. Отримані гістологічні препарати досліджували за допомогою бінокулярного мікроскопа XSP-139 ТP із системою аналізу зображення. Мікрофотографії робили за допомогою цифрової відеокамери PLА662, під'єднаної до мікроскопа. Аналіз зобра- 


\section{ВЕТЕРИНАРНА МЕДИЦИНА}

ження проводили за допомогою програми «Відео Тест».

Контролем слугували 10 бичкових риб, що не були заражені личинками нематоди.

Результати досліджень. Відмічено, що під час проведення систематичного контролю за морфологічним станом печінки риб, які піддаються антропогенному впливу, можна своєчасно виявити порушення екологічної рівноваги у водоймах і провести заходи профілактики 3 метою недопущення їх захворювань [5].

Відомо, що печінка риб є багатофункціональним органом. Вона бере участь у вуглеводному, жировому, білковому та вітамінному обмінах, виконує бар'єрну функцію, затримуючи i знешкоджуючи отруйні речовини, що потрапляють в організм [5].

Печінка риб швидше інших органів реагує на зміну умов зовнішнього середовища. Водночас спостерігаються різного роду патологічні процеси, які характеризуються певними структурними змінами.

Гепатоцити - це є власні клітини печінки, полігональної форми. Їх ядра, розташовані в центрі клітини, зазвичай мають округлу форму, діаметром до 10 мк. Хроматин в ядрі розподілений по ядерній оболонці або близько до добре помітних великих ядерець. Кількість ядерець коливається від одного до трьох. У паренхімі печінки тягнуться печінкові артерії, вени і жовчні судини, що збирають жовч, яка виробляється печінковими клітинами. Жовчні протоки проводять жовч у жовчний міхур. Жовч, завдяки лужній реакції, нейтралізує кислу реакцію шлункового соку. Вона емульгує жири, активує ліпазу - фермент підшлункової залози. 3 травного каналу вся кров повільно протікає через печінку. В печінкових клітинах, крім утворення жовчі, відбувається знешкодження сторонніх білків і отрут та відкладається глікоген. Кров, що пройшла через печінку, по печінковій вені прямує до серця.

В експериментальному матеріалі бичкових риб (бичків-пісочників) були виявлені личинки нематоди Eustrongylides exisus, які локалізувалися в черевній порожнині тіла, на поверхні кишечника, печінці та серозних покривах (рис. 1).

Зараженість бичкових риб личинками нематоди Eustrongylides exisus наведено у таблиці.

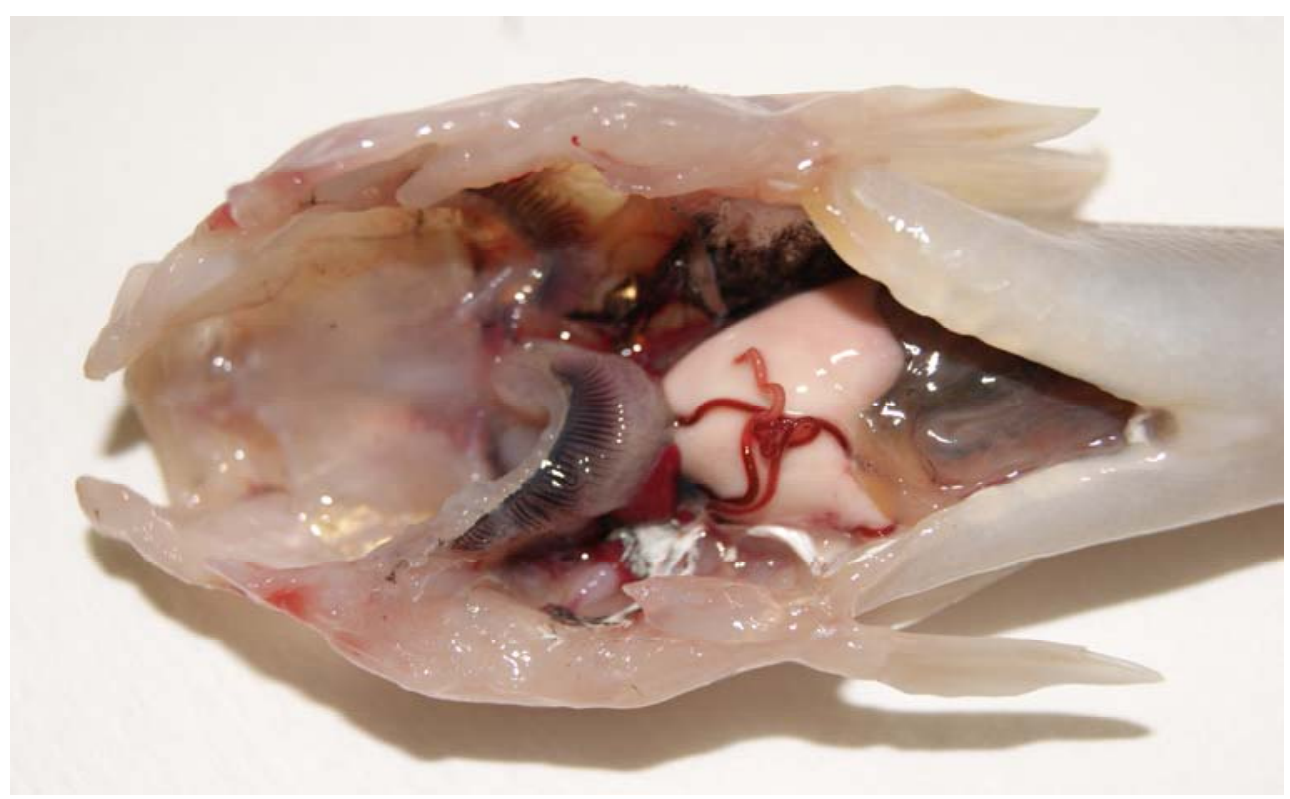

Рис. 1. Личинки нематоди Eustrongylides exisus на поверхні печінки бичка-пісочника

Зараженість бичкових риб личинками нематоди Eustrongylides exisus

\begin{tabular}{|c|c|c|}
\hline Зразок & Кількість личинок, екз. & Локалізація личинок \\
\hline 1 & 2 & На поверхні печінки \\
\hline 2 & 2 & У порожнині тіла \\
\hline 3 & 4 & На поверхні печінки \\
\hline 4 & 3 & На поверхні печінки \\
\hline 5 & 3 & У порожнині тіла \\
\hline
\end{tabular}


Під час мікроскопічного дослідження у зразках 1, 2, 4, 5 виявляли залишки структури печінки 3 ознаками жирової дистрофії. Гепатоцити були збільшені в об'ємі, округлої форми, їх ядро відтиснене до оболонки клітини. Ядра зменшені в об'ємі, неправильної форми, що свідчило про явище пікнозу (рис. 2). Відмічали лізис ядер.
В окремих ділянках виявлені клітини Купфера (рис. 3).

Виявлені лімфоїдно-лейкоцитарні інфільтрати в паренхімі печінки, навколо судин (периваскулярні муфти) (рис. 4) та в судинах (ендоваскулярні муфти) (рис. 5).

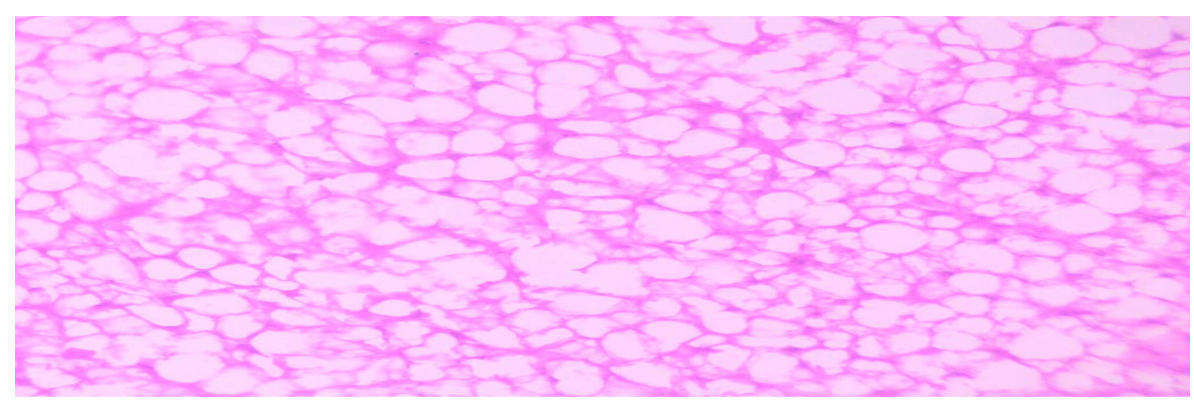

Рис. 2. Жирова дистрофія печінки (жсирова інфільтрація).

Фарбували гематоксиліном Ерліха та еозином (збіл. 10х40).

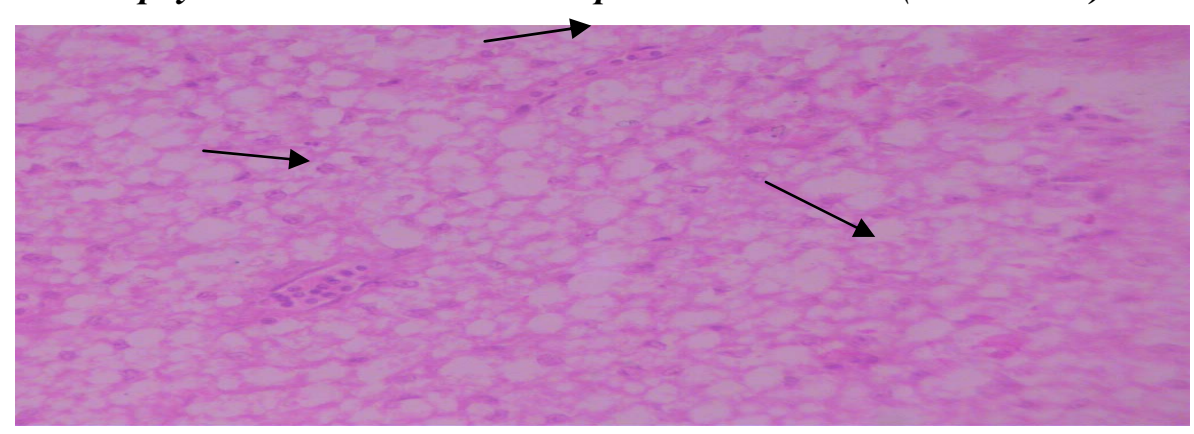

Рис. 3. Клітинні інфільтрати в стінках судини. Клітини Купфера в печінці. Фарбували гематоксиліном Ерліха та еозином (збіл. 10х40)

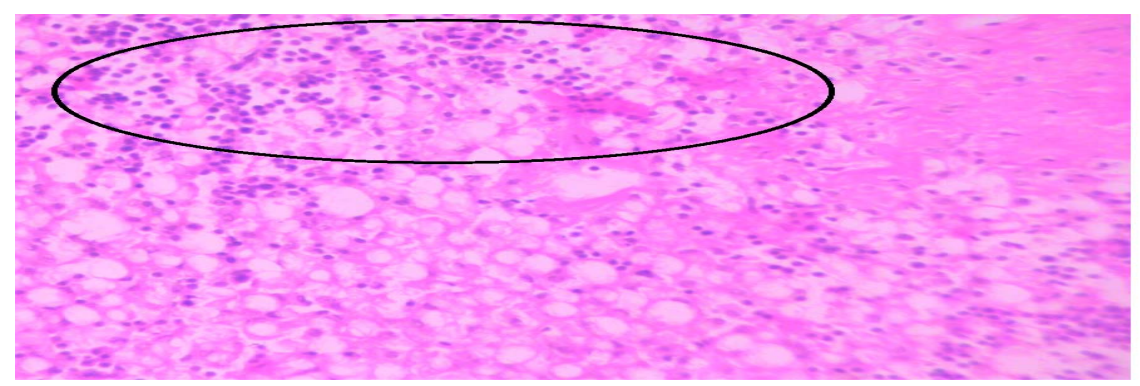

Рис. 4. Жирова дистрофія печінки. Лімфоӥдно-лейкоцитарні клітинні інфільтрати в паренхімі (периваскулярні муфти). Фарбували гематоксиліном Ерліха та еозином (збіл. 10х40)

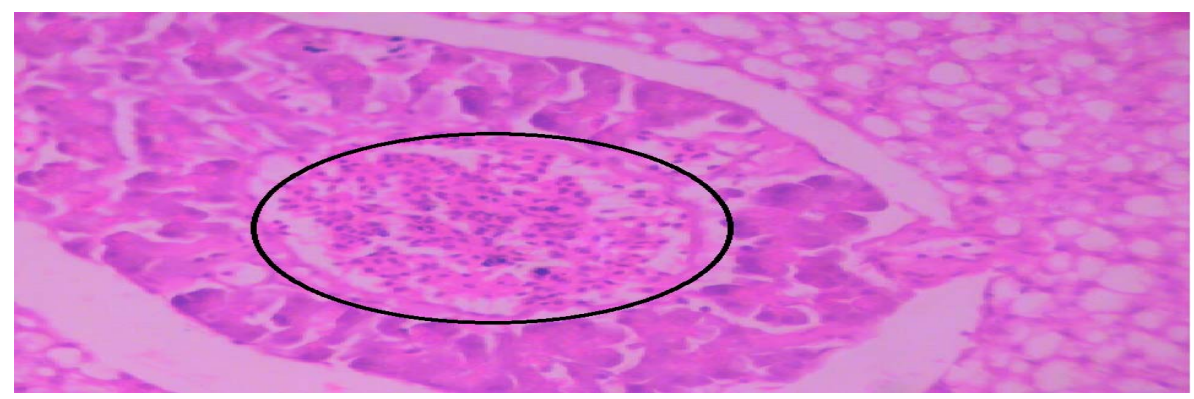

Рис. 5. Клітинний (лімфоӥдно-лейкоцитарний) інфільтрат у судинах печінки - ендоваскулярні муфты. Фарбували гематоксиліном Ерліха та еозином (збіл. 10х40) 


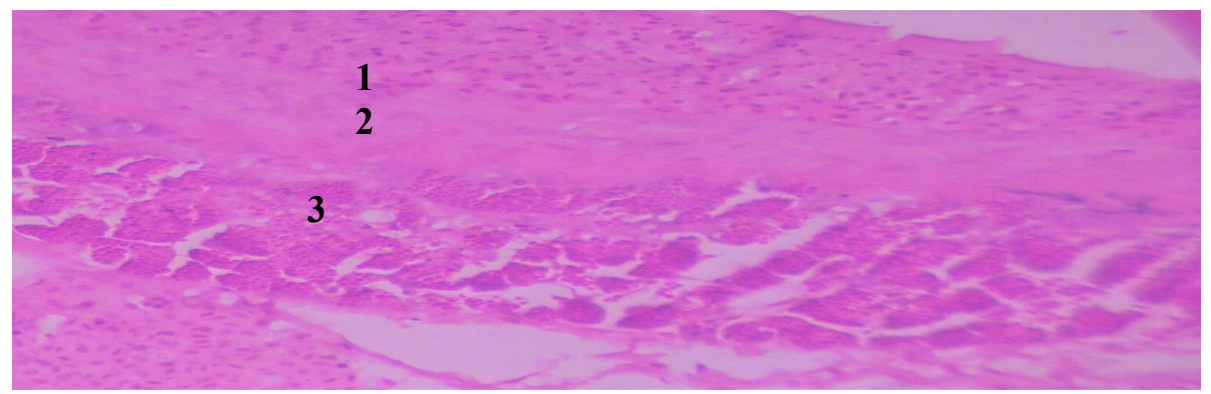

\section{Рис. 6. Атрофія паренхіми печінки (1 - зона запалення навколо паразита, 2 - сформована сполучно-тканинна капсула, 3 - крововилив у капсулу). Фарбували гематоксиліном Ерліха та еозином (збіл. 10х40)}

У зонах клітинних інфільтратів ядра в гепатоцитах відсутні. Водночас гепатоцити представлені аморфною безструктурною масою. В окремих місцях навколо клітинних інфільтратів помітні розростання сполучної тканини.

У зразку 3 виявлені залишки структури печінки з ознаками жирової дистрофії. Паренхіма печінки атрофована внаслідок здавлювання личинкою паразита, морфологічну структуру якого чітко помітно на гістологічному зрізі (рис. 6).

Навколо паразита добре помітно зону запалення. Це є запальний клітинний інфільтрат поліморфного складу (лейкоцити, лімфоцити, гістіоцити). Навколо зони запалення знаходиться сполучнотканинна капсула, в якій виявлені крововиливи. Помітним $є$ відкладання пігменту коричневого кольору в сполучнотканинну капсулу навколо паразита. В окремих ділянках навколо деформованих без'ядерних гепатоцитів у стані некрозу виявлені клітини Купфера.

Водночас паренхіма печінки контрольних зразків утворена трабекулами, що переплітаються та анастомозують 3 вузьким центральним просвітом. Спостерігається жирова дистрофія печінки (жирова інфільтрація), що є нормою. Гепатоцити збільшені в об'ємі, округлої форми, ядро

\section{БІБЛІОГРАФІЯ}

1. Абдуллаєв H. Х. Печінка при інтоксикаціях гепатотропними отрутами / H. Х. Абдуллаєв, Г. Я. Карімов // Медицина. - Ташкент, 1989. - 96 с.

2. Алтуфьев Ю. В. Печінка каспійських осетрових в умовах антропогенного забруднення середовища / Ю. В. Алтуфьев // Екологічні та морфофункціональні основи адаптації гідробіонтів : тези доповідей симпозіуму, присвяченого 90-річчю з дня народження проф. М. Л. Гербильського. - Л., 1990. - С. 3-5.

3. Атлас микрофотографий по нормальной гистологии и эмбриологии : [под ред. Л. И. Фа- відтиснене до оболонки клітини. Ядра зменшені в об'ємі, неправильної форми (пікноз), спостерігається також лізис ядер. Ділянки 3 жировою дистрофією чергуються 3 ділянками незміненої паренхіми печінки. Гепатоцити незміненої паренхіми печінки риби полігональної форми. Ядра округлої форми розташовані в центрі клітини. Зустрічаються пусті та кровонаповнені судини.

Висновок. У печінці бичкових риб, уражених личинками нематоди Eustrongylides exisus, виявлено патологічний процес 3 певними гістологічними змінами. Характерними були зміни для вогнищевого гепатиту. Гепатоцити збільшені в об'ємі, округлої форми, ядро відтиснене до оболонки клітини. Ядра зменшені в об'ємі, неправильної форми (пікноз). Відмічається лізис ядер. В окремих ділянках виявлені клітини Купфера. Помітні лімфоїдно-лейкоцитарні інфільтрати в паренхімі печінки, периваскулярні та ендоваскулярні муфти. У зонах клітинних інфільтратів ядра в гепатоцитах відсутні. Відмічено, що гепатоцити представлені аморфною безструктурною масою. В окремих місцях навколо клітинних інфільтратів виявлено розростання сполучної тканини, що є захисною реакцією організму на наявність личинок нематоди Eustrongylides exisus.

мина]. - М. : Медицинская литература, 1957. C. $87-110$.

4.Вавилов Ю. Л. Гистологическая и гистохимическая характеристика жизненно важных органов европейского карпа в норме и патологии, разводимого в водоемах ТЭЦ / Ю. Л. Вавилов, В. П. Смирнов // Региональные проблемы экологической генетики и пути их решения : тезисы доклада научно-практической конференции, Саранск, 17-18 октября, 1996. - Саранск, 1996. - C. 5. 


\section{ВЕТЕРИНАРНА МЕДИЦИНА}

5.Калашникова М. М. Особенности ультраструктуры клеток печени в сравнительноморфологическом ряду животных и их значение // Бюллетень экспериментальной биологии и медицины, 1996. - №6. - С. 604-609.

6. Карманова Е. М. Диоктофимидеи животных и человека и вызываемые ими заболевания // Ocновы нематодологии / Е. М. Карманова ; [под ред. К. И. Скрябина]. - М. : Наука, 1968. - №20. $-262 \mathrm{c}$.

7. Федорова Н.Н., Крючков В. Н., Зайцев В. Ф. Морфологічна характеристика печінки риб у су- часних екологічних умовах / Н. Н. Федорова, В. Н. Крючков, В. Ф. Зайцев // Російські морфологічні відомості. - 1999. - №3-4. - С. 174-180.

8.Da P. E., Coox S. J. Go na D. Sublethal responses to pesticides of several species of Australian freshwater fish and crustaceans and rainbow trout // Environ. Toxicol. and Chem. - 1994. - №8. - P. 1341-1354.

9. Moravec $F$. Parasitic nematodes of freshwater fishes of Europe. - Dordrecht / Boston / London : Kluwer Acad. Publ., 1994. - 473 pp. 